\title{
Action Research on a WebQuest as an Instructional Tool for Writing Abstracts of Research Articles
}

\author{
Krismiyati Latuperissa ${ }^{\mathrm{a}, *}$ \\ ${ }^{a}$ Satya Wacana Christian University, Indonesia
}

\begin{abstract}
The massive growth of and access to information technology (IT) has enabled the integration of technology into classrooms. One such integration is the use of WebQuests as an instructional tool in teaching targeted learning activities such as writing abstracts of research articles in English for English as a Foreign Language (EFL) learners. In the academic world, writing an abstract of a research paper or final project in English can be challenging for EFL students. This article presents an action research project on the process and outcomes of using a WebQuest designed to help 20 Indonesian university IT students write a research article's abstract in English. Findings reveal that despite positive feedback, changes need to be made to make the WebQuest a more effective instructional tool for the purpose it was designed.
\end{abstract}

\begin{abstract}
Abstrak
Maraknya perkembangan dan akses ke teknologi informasi (IT) mendorong pengintegrasian teknologi ke ruang kelas. Salah satu integrasi tersebut adalah penggunaan WebQuest sebagai sarana pembelajaran untuk latihan menulis abstrak artikel penelitian bagi siswa kelas EFL atau Inggris sebagai Bahasa Asing. Di dunia akademik, menulis abstrak makalah penelitian atau tugas akhir dalam bahasa Inggris bisa menjadi praktek yang sulit bagi mahasiswa EFL. Artikel ini mengupas penelitian tindakan mengenai proses dan manfaat WebQuest dalam membantu mahasiswa IT di 20 universitas di Indonesia menulis abstrak riset dalam bahasa Inggris. Penemuan penelitian menunjukkan bahwa, disamping masukan yang positif, ada beberapa hal yang perlu diubah supaya WebQuest menjadi sarana belajar yang lebih efektif sesuai dengan tujuan pembuatannya.
\end{abstract}

Key Words: WebQuest, Instructional Tool, Writing Abstracts, Computer Assisted Language Learning, Research Article

\section{Introduction}

The development of information technology (IT) has created new learning opportunities in classrooms across the world. Such opportunities are facilitated by access to the World Wide Web, which teachers and students can use as a resource for exploring and gathering information. A WebQuest is one example of how teachers can integrate such technology into their instruction. This article will discuss the implementation of a WebQuest intended to help Indonesian university students in an English as a Foreign Language classroom write an English abstract for a research article.

*Corresponding author. Address: Faculty of Information Technology, Satya Wacana Christian University, Jl. Diponegore 52-60 Salatiga, 50711 Central Java. Email: krismi@staff.uksw.edu.
The 20 students involved in this study are final year information technology students at Satya Wacana Christian University (SWCU), a private university in Central Java, who learned English for approximately six years in their secondary schools as part of the national curriculum in Indonesia. Overall, their existing level of English is either low-intermediate or intermediate. Their exposure to English is primarily limited to Internet as they search for resources to support their research or keep up with the latest information.

For these students, the main issue in using English in their studies arises when they have to write an English abstract of their final project, which is a requirement for getting their degree. This degree requirement supports John M. Swales' (1990) observation that research articles written in a language other than English are sometimes required to have abstracts written in English. Instead of following the academic standards of a given field for structuring 
abstracts, students tend to translate from their first language (i.e., Bahasa, Indonesia) to English. Alternatively, sometimes students end up handing in abstracts translated by someone else because they have never been taught how to write an abstract in English. Further complicating the situation for students is the fact that the focus in their English courses tends to be on writing short essays. The technique for writing abstracts is not taught, which is particularly significant given that abstract writing is a distinctive kind of writing that varies by field, in this case IT. A genreanalysis approach (Swales and Feak 2009) is used in this action research project to evaluate the effectiveness of a WebQuest designed by the author to help IT students write an abstract in English.

\section{Literature Review}

In designing a lesson or an aid for learning, beliefs about language learning and teaching shape the product one will produce. Kathleen Graves (2000) states that the beliefs of the individual designing curricula, lessons, or materials play an important role in shaping the lesson. In the context of this study, the teacher-researcher believes that students learn more provided they are exposed to what they are expected to learn. As this WebQuest is aimed to help students to write an abstract of a research article in English, they need exposure to English abstracts accompanying research articles (RAs). Additionally, students learn better when they are able to practice a given skill. Randi Reppen (2002) maintains that exposing and giving students practice in genre is crucial for English as a Foreign Language (EFL) students. In line with that idea, Joy Reid (1993) advocates that genre analysis, which looks at the organization of different genres, can assist EFL students in becoming stronger writers and readers. This means that by exposing students to genre analysis, in this case abstract analysis, they will be able to write abstracts more effectively. They will understand how an abstract should look and what constitutes a good abstract in their field of study.

\section{Genre}

Genre can be defined as a type of text that has a specific communicative function with a distinctive structural or discourse pattern (Swales 1990; Holmes 1997; Gibbon 2002). Genres usually belong to a particular discourse community in which interest and knowledge can be shared and promoted. In the context of this study, the discourse community being looked at is the information and communications technology community. This community uses certain genres their members have become familiar with because directly or indirectly their work influences the discourse of other community members (Swales1990).

Research Article. The research article (RA) is a prestigious genre that is produced in large numbers every year (Swales 2004). Martin Hewings (2001) says that most disciplines use research articles to present new knowledge claims. In other words, RAs provide a means for researchers to be recognized in their field. The RA is also used as a means for presenting and disseminating what a given research community has been researching so people outside that community can learn from and keep up with the latest developments in that field; this is vital for developing and maintaining the relationship between a research community and outsiders (Giannoni 2008).

The RA is a common product in academic writing both at the undergraduate and graduate levels that students must learn to master (Samraj 2004). University students, as novice scholars often new to a given research community, are typically familiar with research articles since they read them throughout their studies and refer back to them as references and models for producing a similar kind of writing. In an attempt to facilitate mastery, Swales (1990), Richard Holmes (1997), Santiago Posteguillo (1999), and Betty Samraj (2004) focus on the organization of RAs, many of which usually follow a similar pattern. Samraj, in her investigation of science RAs, states that although texts vary in some way, they share the same organizational pattern or structure of introduction, method, results and discussion (IMRD). Once students learn this pattern, they will be better able to understand RAs and write their own RAs, thus supporting their entry into their research community.

Abstracts. The abstract is a research process genre (Swales 1990) and can be categorized as an independent genre in academic writing (Swales 1990; Lores 2004). According to Thomas N. Huckin (2001) and Rosa Lores (2004), abstracts have become a crucial genre, particularly for science and technology as they help the reader grasp what is new in terms of methodology and results before they continue to read the entire article. In this way, abstracts also function as a screening device (Huckin 2001), front/summary matter (Swales 1990) or gateway (Lores 2004) for readers to decide whether or not they will read the research article. In addition, knowing in advance what will be discussed in a paper could decrease the amount of time needed to scan or read the article.

Features of abstracts in research articles. An abstract, much like the research article itself, is usually comprised of four primary sections: introduction, method, results/discussion, and conclusion 
(Swales 1990; Ayers 2008). Abstracts vary in length, for example many are between 80 to 200 words depending on the journal. Journals will often provide this information in the instructions they provide for researchers wanting to submit their manuscript for consideration.

Moves of an abstract. Move as defined by Swales and Christine B. Feak (2008) is "a functional term that refers to a defined and bounded communicative act” (35). For example an abstract presented in a conference will typically have five move structures: an outline of a research field, justification for the study, an introduction to the paper, a summary of the research, and a synopsis of the results (32). Sometimes, moves in an abstract are identified by the use of the tense (Swales 1990; Ayers 2008).

This study uses a modification of the traditional IMRD model as it is much easier for students to analyze compared to identifying kind of lexis or tenses as suggested by Swales (1990) and Gael Ayers (2008). In recognizing the IMRD and conclusion (IMRDC) moves, students can always refer to the complete research article as the moves usually serve as the research article's primary headings. The moves of the IMRDC model are explained as follows (Huckin and Olsen 1991; Lores 2004; Samraj 2005):

- The introduction usually outlines the author's research objective or problem.

- The methods move provides information on how the research was carried out and sometimes includes the data used in the study.

- The results move provides a summary of the findings.

- The discussion move is an interpretation of the results, their implications or suggestions for further study.

- The conclusion concludes the research.

These moves are not fixed; it is possible for two moves to appear as one single move due possibly to the typically predetermined length of an abstract. For example, in Ayers' (2008) study on abstracts of scientific research articles, he found that sometimes the introduction and methodology appear as a single move. In other cases, sometimes the results and discussion are presented in one move (see examples provided by Martin 2003). There are some occasions where the author mentions the conclusion of the study in their abstract. However, it might be presented as a separate move or it could be presented in combination with the discussion (Martin 2003).

\section{Theoretical Framework}

In language learning, Lev Vygotsky's (1978) Zone of Proximal Development (ZPD) and scaffolding and Stephen D. Krashen's (1981) input model are key theories. While Vygotsky's focus was human learning or intellectual development, Krashen's focus has been second language learning and acquisition, the model for which closely resembles Vygotsky's ZPD. Both take place in social environments whereby interaction with peers or teachers is a necessary condition for development.

\section{Zone of Proximal Development}

Vygotsky's ZPD refers to "the conceptual space or zone between what a child is capable of doing on her own and what she can achieve with assistance from an adult or more capable peer" (Daniels 2001). The WebQuest designed for the pilot study reflects the idea of ZPD as it works within the zone both of what students are capable of or already know and that which they do not know and therefore need assistance with. Students are familiar with Internet, RAs and the notion of RAs having abstracts. They are not familiar, however, with the structure of an abstract and as a result how to write one in English. For this they need assistance from a more capable party. Capitalizing on their interest in and knowledge of Internet, a WebQuest is used an instructional tool to help them advance their ability to write an abstract in English.

Closely related to ZPD is scaffolding. Learners must first be in their ZPD for scaffolding to be used effectively. In the ZPD, scaffolding is an aid that allows learners to accomplish a given task. Scaffolding is eventually removed so learners can accomplish and ultimately master the given task on their own. A learner then enters a new ZPD and the process is repeated.

\section{Scaffolding}

To realize all the objectives set in designing the WebQuest, it must provide what Vygotsky calls scaffolding. Scaffolding is a form of skill or knowledge building in which a learner will build his or her skills based on the ability of mastering more simple skills. In this way, a foundation is built from which to build upon. According to Harry Daniels (2001), scaffolding is a form of assistance given to learners so they can carry out a task that was initially beyond their capacity. For example, if a language learner confuses the present and past tense, a teacher-guided exercise differentiating the two will be the scaffolding. After the past and present tense have been mastered, or are close to being mastered, the teacher can move to more advanced verb tenses while continuing to engage the learner with tenses that have already been 
studied and mastered. Furthermore, Daniels explains that scaffolding allows the learner to complete a task within his or her existing capabilities before moving to the one beyond his or her capacity. In short, all the supportive efforts given to learners to help them reach their goals constitute scaffolding (Schaffer 1996).

The use of a WebQuest in this study would qualify as scaffolding. The WebQuest is designed to provide assistance to students by providing information on how abstracts are structured in addition to providing step-by-step guidance on how to identify the elements that make up the structure. The students might already be familiar with seeing or reading abstracts, however, it is important they know exactly which part of a RA the abstract corresponds with. After they are able to recognize an abstract along with which part refers to which feature of a RA, they will perform the bigger task of writing an abstract in English for a given article.

\section{Input}

A complementary theory that frames this research is what Krashen (1981) calls comprehensible input. Initially applied to second language acquisition, Krashen asserts that students acquire a language by understanding what is "a little beyond" their current level of competence or input(i)+1. This means that it is necessary to expose students to a level slightly higher than what they have already acquired. In terms of writing an abstract in English, students have already been at the level where they can understand English and produce a short essay of 200-250 words in their major. Students need to be challenged to go beyond their existing knowledge or skill level if they are to produce an abstract of a scientific RA. This requires students to be given input a little beyond their existing competence, but not as far as $\mathrm{i}+2$ as they will be overwhelmed or not at $\mathrm{i}+0$ which would result in no challenge at all (Brown 1993). While paying attention to the level of input, scaffolding is provided to better ensure they will be able to achieve the level they are expected to.

Noticing is also important in this process in that students go through a process of bringing some stimulus to their attention (Schmidt 1990). As Schmidt (1990) mentions, noticing is needed in order to convert input into intake. Intake is what students incorporate in order to develop their foreign language learning (Mitchell and Myles 1998). In this research, students pay special attention to abstracts and its features, including specific words or linguistic features that will later be incorporated into their own abstracts.

\section{WebQuest Design Rationale}

\section{WebQuest Design}

Bernie Dodge (1997a) defines WebQuest as "an inquiryoriented lesson format in which most or all the information that learners work with comes from the web” (1). It is a web-based learning tool that serves more as a scaffold or form of assistance that helps learners learn and perform a more advanced skill set based on their existing knowledge. When compared to students' day-to-day Internet surfing, the scope is typically much smaller but more focused.

Dodge (1997b) explains that there are two levels of a WebQuest: a short-term WebQuest, which might be completed in one to three class periods, and a long-term WebQuest, which is designed for a one-week to one-month class discussion. Regardless of the type of WebQuest, Dodge (1997a) attributes the following six features to a well-designed WebQuest:

1. An introduction gives background information on the WebQuest, including its purpose.

2. The task tells students what they are supposed to accomplish to achieve the set objective(s). It should be interesting and manageable for students to carry out.

3. A set of information sources for completing the task should be provided. These might be links to a particular website, online database, downloadable file or even print materials such as books that students have access to.

4. Also provided is a description of the process students go through to complete the given task. It is helpful if the process is broken down into several steps and described as clearly as possible.

5. Students also need guidance on how to use all the resources as well as how to organize the information they are learning. Guidance might take the form of a question, diagram, direction, instruction, etc.

6. A conclusion tells students when they have reached the end of the quest and summarizes the learning points of the given task.

\section{Action Research WebQuest Design}

The WebQuest used for this study was designed by the author to teach advanced IT students how to write an abstract of a research article in English. This topic is relevant because they will have to produce a similar kind of writing as they approach the end of their degree program. Furthermore, many will use the skill of writing abstracts in English in their professional lives. 
WebQuests are typically designed to move between webpages, but the WebQuest for this research was designed using Google Docs. Doing so enabled ease of access to predetermined information. Instead of being directed to a webpage to search for abstracts or research articles, a hyperlink directed students to research articles in Google Docs. The selected research articles did not have an abstract, which gave students the opportunity to first read the articles before writing their own and comparing it to the (missing) abstract for one of the RAs they read. This WebQuest used research articles from the Journal of Information Technology.

The WebQuest features the common characteristics as described by Dodge (1997a) in the preceding section. The introduction, task, process, and conclusion used in the WebQuest for this study are presented below. The other two characteristics, information sources and guidance, are less concrete. Information sources for this WebQuest were in the form of hyperlinks to sample abstracts and RAs students have to access; the guidance itself was in the form of instruction in each stage. There is no explicit stage that refers solely to information sources and guidance. They are integrated into various sections when necessary.

Introduction. The introduction provides a few sentences on the significance of abstracts and outlines what the learners are expected to accomplish through the WebQuest (see Figure 1).

Figure 1. WebQuest Introduction

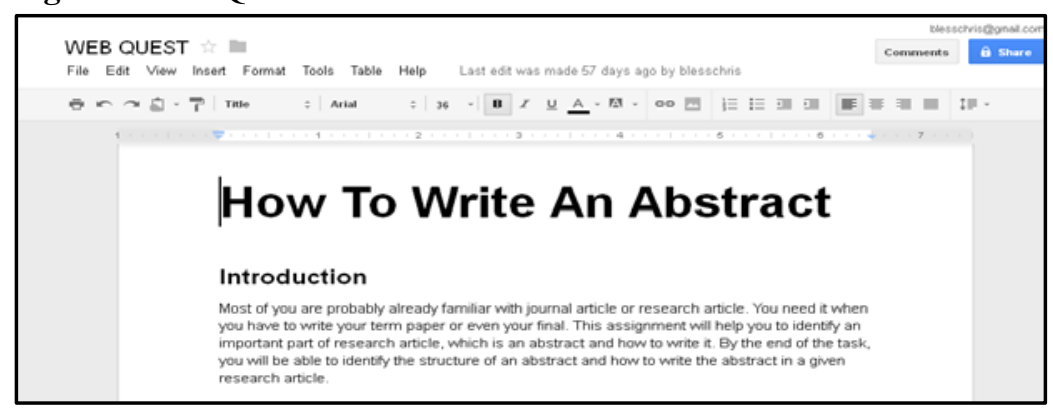

Task. The task section briefly explains what the learners are expected to do. As shown in Figure 2, students are expected to identify the features of an abstract and write an abstract of a given article.
Figure 2. WebQuest Task

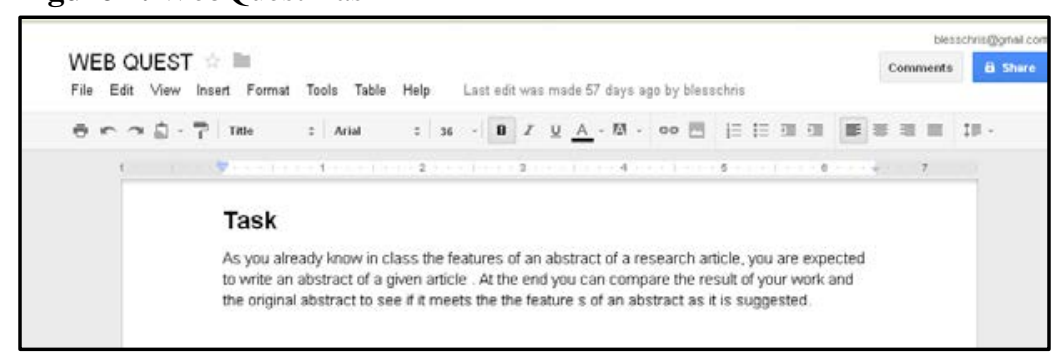

Process. The process component provides step-by-step guidance on how to accomplish the task. This WebQuest follows Hammond's teaching-learning cycle (Burns, 2001) of modeling, joint negotiation of text, and independent construction.

For the modeling stage, the WebQuest presents examples of RAs with abstracts. The purpose of the modeling stage is to increase students' understanding of the purpose of the text, its overall structure, and its language features (Gibbon 2002, 64). In this stage, students are asked to identify the distinctive language found in the abstract, including that which marks characteristic features and/or moves. After they have identified these elements and their language, the WebQuest will take them to a page with the features of the abstract correctly identified so they can check their understanding/answers for accuracy.

After the modeling stage, students enter the joint negotiation stage. Here the teacher and students decide upon the research article for which they will collectively rewrite an abstract for. This stage should employ all the features previously noted so students can produce a similar piece of writing.

Students are then navigated to a page that provides a research article missing an abstract. In this independent construction stage, students will have to write an abstract for the RA. It is expected that students will use utilize their knowledge of abstract features that they learned in the previous stage.

From the first modeling stage until the final independent construction stage, students should have the scaffolding they need to effectively perform all the tasks; it is expected that students will have gained the confidence to write their own abstract (Gibbon 2002).

Conclusion. The conclusion acknowledges that the student has accomplished the task and provides positive reinforcement such as positive feedback, as shown in Figure 3. 
Figure 3. WebQuest Conclusion

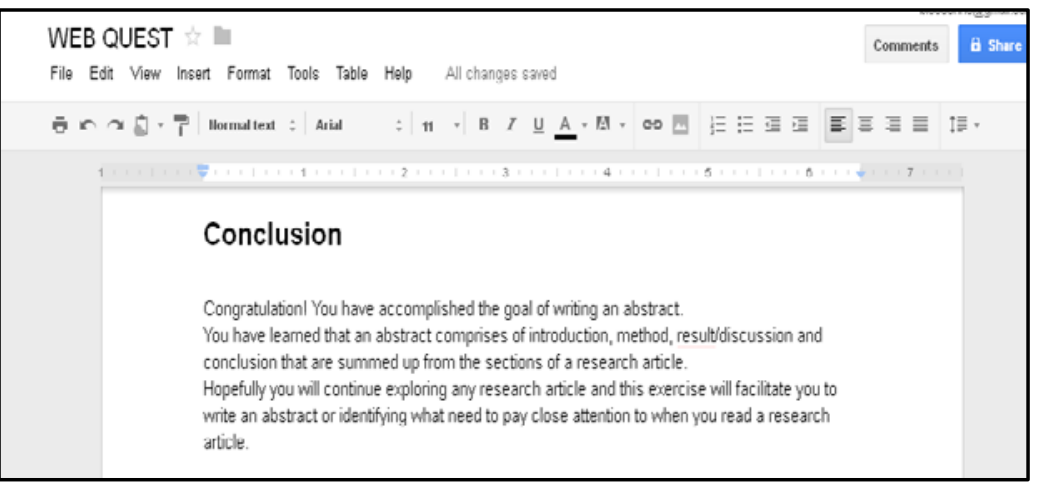

Though the WebQuest follows Dodge's characteristics for a well-designed WebQuest, it also employs the traditional taskbased approach by Dave Willis and Jane Willis (2007). This entails presenting students with an example, providing a task or activity based on the example, and finally producing an outcome that meets specified objectives and exposes them to real language. In this research, the WebQuest was designed to address two important components, text and task.

\section{Methodology}

Action research, as a form of collaborative inquiry, is used to guide the methodology for this research. It aims to work with practitioners in identifying practical solutions for real problems while connecting theory to practice. In doing so, subjectivity is emphasized as practitioners, according to Craig A. Mertler (2012), go through the flexible and at times iterative steps of:

- Identifying and limiting the topic

- Gathering information

- Reviewing relevant literature

- Developing a research plan

- Implementing the plan and collecting data

- Analyzing data

- Sharing and communicating results

- Reflecting on the (research) process

This research was collaborative and practical in that it worked with students in evaluating an instructional tool designed to facilitate students' knowledge of key features of abstracts of research articles and their ability to write them in English.

Twenty advanced IT students at SWCU, a private university in Central Java, participated in this research during the first semester of the 2011-2012 academic year. The students were enrolled in a mandatory English language course as part of the curriculum offered by the Information Technology Faculty at SWCU. The class met once a week for 100-minutes. The WebQuest activity took place over two 100-minute classroom sessions. In the first class, the teacher introduced the features of an abstract and presented some examples and exercises on identifying the features of previously selected abstracts. At this point, students were encouraged to ask questions and discuss the features of an abstract. This was done first through students working in pairs before moving to a class discussion in which the teacher provided feedback. At the end of the class they were able to identify the features of an abstract based on what they learned during class. In the second class, the previous discussion was reviewed and students practiced writing an abstract for a given research article. The teacher was present to provide assistance if students experienced difficulty with the exercise. The students finish with an abstract of a research article in English.

All 20 students participated in the WebQuest and its evaluation, which included going through the various stages of the WebQuest and providing feedback at the end of the WebQuest through a short anonymous paper survey. The survey asked the following four closed- and open-ended questions:

1. Do you find this WebQuest is useful for your study? How?

2. Does it give enough support for you to write an abstract? How?

3. Do you miss something on this WebQuest?

4. Please give any suggestions for this WebQuest.

Survey data were also collected and analyzed in the first semester of the 2011-2012 academic year. The data collected were first analyzed individually. Common responses were then grouped together until all possible categories of responses were represented for each question. Illustrative responses representing each category for each question are highlighted below in the findings and discussion section.

\section{Findings and Discussion}

Overall, the WebQuest proved to be a valuable instructional tool in teaching students how to write in English an abstract for a research article. The students said that the WebQuest was useful for their studies, which is reflected in some illustrative comments to the first survey question:

It is very helpful for me. Now, I know how to write an abstract. (S1) 
Yes, according to me it's very useful for my study because I can understand how to make an abstract. (S3)

Yes, because the feature of an abstract in this WebQuest is easy to understand. (S7)

Yes, I think is useful for my study because from this WebQuest I can learn more easily. (S10)

From the feedback given by the students, it is clear that the WebQuest served its function as scaffolding for the students by considering their ZPD. The students internalized the information and knowledge on how to write an abstract; they were able to convert input to intake (Schmidt 1990).

Regarding the design of the WebQuest, most students said that the WebQuest was interesting and provided clear information on what they had to do. They said that they did not get lost in navigating within and between the pages.

It is quite good. The flow and menu is easy to understand and the materials provided are good. (S8)

The WebQuest design and layout, however, did not satisfy all the students. Representative comments for those who had suggestions on how to improve the design are as follows:

Using nicer images/photos in your WebQuest might make your WebQuest more interesting to users and it may help building a passion for learning. (S12)

Maybe, you should put some graphical picture or a graphical character to light-up your WebQuest. (S13)

Furthermore, students said that the WebQuest was effective because it uses real RAs that they may use in their own research. This may have motivated them in doing the WebQuest as it has a clear purpose for developing their skills and has real world value.

When learning a foreign language, realia is a form of motivation as it provides context, comprehensible input and meaningful practice activities (Krashen 1981). As student comments demonstrate, the WebQuest and its activities, as realia, advanced their skill and ultimately confidence.

This WebQuest is useful for me. I can use it for my study. It gives good reference for me in writing an abstract later on. (S8)
Because I know how to write an abstract using this WebQuest, I will not need to worry anymore if I have to write an abstract in the future. (S10)

Before they worked with the WebQuest, students did not know or might not have been certain about what an abstract consists of. After working with the WebQuest, they shared that they know more about the features of an abstract. One of the students said that the WebQuest helped him in writing an abstract as he was able to access the information he needed to do so.

Despite the success of the WebQuest, the following modifications could be made to strengthen its accessibility and learning points:

- Highlighting the areas in the RA the abstract was derived from. This will allow students to make connections between the abstract and the article and give them a clearer idea of how to produce their own abstract later on.

- Adding a component that covers keywords. This WebQuest did not help students in deciding keywords to include for the abstracts. A separate WebQuest could be designed to cover this or it could be an added feature to the current WebQuest.

- Providing information on the approximate length of abstracts. This was missing from the WebQuest but is necessary so students know the maximum word length of an abstract or how to find out what that might be.

\section{Conclusion}

The WebQuest designed in this action research project proved helpful in broadening the 20 participating IT students' knowledge about and ability to write abstracts in English for research articles. The use of realia in the WebQuest and a WebQuest's inherent focus on task-based learning contributed to student interest, motivation, and success. Modifications, however, are needed to refine any instructional tool. The primary outcome from the research is that the WebQuest should be modified to include information on abstract length and keywords. A WebQuest is one example of how teachers can integrate technology into classrooms, which is a growing area of interest as information technology creates new learning opportunities and becomes more accessible across the world. 


\section{References}

Ayers, Gael. 2008. "The Evolutionary Nature of Genre: An Investigation of the Short Texts Accompanying Research Articles in the Scientific Journal Nature.” English for Specific Purposes 27 (1): 22-41.

Brown, Douglas. J. 1993. Principle of Language Learning and Teaching. New York: Prentice Hall.

Burns, Anne. 2001. "Genre-Based Approaches to Writing and Beginning Adult ESL Learners.” In English Language Teaching in Its Social Context: A Reader, ed. Christopher N. Clandlin and Neil Mercer (pp. 200-208). Oxford, UK: Taylor \& Frances, Inc.

Daniels, Harry. 2001. Vygotsky and Pedagogy. London: RoutledgeFalmer.

Dodge, Bernie. 1997a. What is a WebQuest? San Diego, CA: San Diego State University. Available online at: www.WebQuest.org.

Dodge, Bernie. 1997b. Some Thoughts About WebQuests. San Diego, CA: San Diego State University. Available online at: http://webquest.sdsu.edu/about_WebQuests.html.

Giannoni, Davide Simone. 2008. "Popularizing Features in English Journal Editorials.” English for Specific Purposes 27 (2): 212-232.

Graves, Kathleen. 2000. Designing Language Courses: A Guide for Teachers. Boston: Heinle and Heinle.

Gibbon, Pauline. 2002. Scaffolding Language, Scaffolding Learning: Teaching Second Language Learners in the Mainstream Classroom. Portsmouth, NH: Heinemann.

Hewings, Martin. 2001. Academic Writing in Context. Birmingham, UK: University of Birmingham Press.

Holmes, Richard. 1997. "Genre Analysis, and the Social Sciences: An Investigation of the Structure of Research Article Discussion Sections in Three Disciplines.” English for Specific Purposes (16) 4: 321-337.

Huckin, Thomas N. 2001. "Abstracting from Abstracts.” In Academic Writing in Context: Implications and Applications: Papers in Honour of Tony Dudley-Evans, ed. Martin Hewings (pp. 93-103). Birmingham, UK: University of Birmingham Press.

Huckin, Thomas N., and Leslie A. Olsen. 1991. Technical Writing and Professional Communication for Nonnative Speakers of English. Singapore: McGraw Hill.

Krashen, Stephen D. 1981. Second Language Acquisition and Second Language Learning. New York: Pergamon Press.

Lores, Rosa. 2004. "On RA Abstracts: From Rhetorical Structure to Thematic Organization.” English for Specific Purposes 23 (3): 280-302.
Martin, Pedro Martin. 2003. “A Genre Analysis of English and Spanish Research Paper Abstracts in Experimental Social Sciences.” English for Specific Purposes 22 (1): 25-43.

Mertler, Craig A. 2012. Action Research: Improving Schools and Empowering Educators. 3rd ed. Thousand Oaks, CA: Sage.

Mitchell, Rosamond, and Florence Myles. 1998. Second Language Learning Theories. London: Hodder Education.

Posteguillo, Santiago. 1999. "The Schematic Structure of Computer Science Research Article.” English for Specific Purposes (18) 2: 139 -160.

Reid, Joy. 1993. "Historical Perspective on Writing and Reading in the ESL Classroom." In Reading in the Composition Classroom: Second Language Perspectives, ed. J. G. Carson and I. Leki (pp. 33-60). Boston: Heinle and Heinle.

Reppen, Randi. 2002. "A Genre-Based Approach to Content Writing Instruction.” In Methodology in Language Teaching: An Anthology of Current Practice, ed. Jack c. Richards and Willy A. Renandya (pp. 321-327). Cambridge, UK: Cambridge University Press.

Samraj, Betty. 2004. "Discourse Features of the Student-Produced Academic Research Paper: Variations across Disciplinary Courses.” Journal of English for Academic Purposes 3 (1): 522.

Samraj, Betty. 2005. "An Exploration of a Genre Set: Research Article Abstracts and Introductions in Two Disciplines." English for Specific Purposes 24 (2): 141-156.

Schaffer, H. Rudolph. 1996. "Joint Involvement Episodes as Context for Development.” In An Introduction to Vygotsky, ed. Harry Daniels (251-280). London: Routledge.

Schmidt, Richard W. 1990. "The Role of Consciousness in Second Language Learning.” Applied Linguistics 11 (2): 129-158.

Swales, John M. 1990. Genre Analysis. Cambridge, UK: Cambridge University Press.

Swales, John M. 2004. Research Genres: Exploration and Applications. Cambridge, UK: Cambridge University Press.

Swales, John M., and Christine B. Feak. 2008. English in Today's Research World: A Writing Guide. Ann Arbor, MI: University of Michigan Press.

Swales, John M., and Christine B. Feak. 2009. Abstracts and the Writing of Abstracts. Ann Arbor, MI: University of Michigan Press.

Willis, Dave, and Jane Willis. 2007. Doing Task-Based Teaching. Oxford, UK: Oxford University Press.

Vygotsky, Lev. 1978. Mind in Society: The Development of Higher Psychological Processes. Cambridge, MA: Harvard University Press. 